(2) Open Access Full Text Article

ORIGINAL RESEARCH

\title{
Investigating The Antimicrobial Activity Of Different Root Canal Filling Pastes In Deciduous Teeth
}

This article was published in the following Dove Press journal:

Clinical, Cosmetic and Investigational Dentistry

\author{
Leila Basir' \\ Mashallah Khanehmasjedi ${ }^{2}$ \\ Azardokht Khosravi ${ }^{3}$ \\ Sahameh Ansarifar ${ }^{4}$ \\ 'Infectious and Tropical Diseases \\ Research Center of Health Research \\ Institute, Department of Pediatric \\ Dentistry, School of Dentistry, \\ Jundishapur University of Medical \\ Sciences, Ahvaz, Iran; ${ }^{2}$ Department of \\ Orthodoncy, Faculty of Dentistry, \\ Jundishapur University of Medical \\ Sciences, Ahvaz, Iran; ${ }^{3}$ Department of \\ Microbiology, Faculty of Medicine, \\ Jundishapur University of Medical \\ Sciences, Ahvaz, Iran; ${ }^{4}$ Department of \\ Pediatric Dentistry, School of Dentistry, \\ Jundishapur University of Medical \\ Sciences, Ahvaz, Iran
}

Background: The antiseptic property of root canal filling materials is very important for the removal of residual pathogens from root canals. The aim of the current study was to investigate the antimicrobial activity of mineral trioxide aggregate (MTA), calcium hydroxide $(\mathrm{CH})$, Metapex, zinc oxide eugenol (ZOE), and CEM-cement.

Materials and methods: Four standard bacterial strains including Staphylococcus aureus (ATCC 6538), Enterococcus faecalis (ATCC 29212), Pseudomonas aeruginosa (ATCC 27853), and Bacillus subtilis (ATCC 6633) and Candida albicans (ATCC 10231) were used. On five plates containing Brain Heart Infusion (BHI) agar, five cavities were made. Then, the plates were cultured by $0.1 \mathrm{~mL}$ of bacterial suspension with a concentration of 0.5 McFarland. Afterwards, the cavities were filled with the tested materials and were incubated at $37^{\circ} \mathrm{C}$ for 24,48 , and $72 \mathrm{hrs}$. Diameters of microbial inhibition zones were then measured. Results: The highest mean diameter of growth inhibition zones was observed around ZOE and then $\mathrm{CH}$ and $\mathrm{CEM}$-cement. According to the Kruskal-Wallis test, there was a significant difference among the tested groups $(P<0.041)$.

Conclusion: Considering antimicrobial activity, $\mathrm{CH}$ was an acceptable alternative to ZOE. Keywords: filling materials, CEM-Cement, calcium hydroxide, mineral trioxide aggregate

\section{Introduction}

Pulp therapy in children is widely used to prevent deciduous teeth loss. Loss of deciduous teeth due to dental caries can lead to problems such as loss of arch length and inadequate space for permanent teeth. ${ }^{1}$ The main goal of pulp therapy is to remove microorganisms from root canals and prevent their subsequent infections. ${ }^{2}$ The complex morphology of root canals in deciduous teeth makes mechanical cleansing and rinsing difficult. ${ }^{3}$ The most common materials for filling root canals of deciduous teeth include:
1) Zinc oxide eugenol (ZOE)
2) Iodoform-based pastes
3) Calcium hydroxide $(\mathrm{CH})^{3}$

Infectious and Tropical Diseases Research Center of Health Research Institute, Department of Pediatric Dentistry, School of Dentistry, Jundishapur University of Medical Sciences, PO Box 159, Ahvaz 15794-6I357, Iran Email basir_!@yahoo.com
ZOE, as the most commonly used material recommended for the treatment of deciduous teeth, was recommended by the American Academy of Pediatric Dentistry (AAPD) until 2008. ${ }^{4}$ To improve its characteristics and success rate, it has been combined with various materials such as formocresol and cresol. These 
compounds increase its success rate, but they do not make it more resorbable than ZOE alone. ${ }^{5,6}$

Pabla et $\mathrm{al}^{7}$ evaluated the antimicrobial activity of ZOE and Iodoform, KRI, and Maisto pastes on the necrotic deciduous teeth and concluded that the Vitapex paste had the highest antimicrobial activity. In a clinical study, the mixture of zinc oxide, calcium hydroxide, and $10 \%$ sodium fluoride solution was used. It was detected that the rate of resorption of root canals obturated by this mixture was pretty similar to the rate of physiologic root resorption in deciduous teeth. ${ }^{8}$ Pitts et $\mathrm{al}^{9}$ examined the resorption nature of calcium hydroxide and found that the highest rate of resorption of apical plug of this material occurred during the first month.

In a study conducted by Gupta et $\mathrm{a}^{10}$ forty-two necrotic deciduous teeth were selected. The success rate of ZOE was $85.71 \%$ and that of Metapex was $90.48 \%$. In a study by Subramaniam et $\mathrm{al}^{11}$ entitled "Endoflas, Zinc Oxide Eugenol and Metapex as root canal filling materials in primary molars - a comparative clinical study", forty-five primary molars were selected for pulpectomy. Finally, there were no significant differences between the three groups.

In order to increase the chance of success in root canal treatments, materials with high antimicrobial properties are used to fill root canals. ${ }^{3}$ Consequently, the aim of this in vitro study was to evaluate the antimicrobial activity of mineral trioxide aggregate (MTA) and CEM-cement, and calcium hydroxide $(\mathrm{CH})$ and metapex, zinc oxide eugenol (ZOE) in deciduous teeth.

\section{Materials And Methods}

In this study, the following strains were prepared as lyophilized vials from Iranian Research Organization for Science and Technology: Enterococcus faecalis (ATCC 29212), Staphylococcus aureus (ATCC 6538), Bacillus subtilis (ATCC 6633), Pseudomomas aeruginosa (ATCC 27853), and Candida albicans (ATCC 10231). These strains were made in the United States (American Type Culture Collection-ATCC).

To activate bacterial strains, the vials were poured into Trypticase Soy Broth (TSB, Merck, Germany) and were incubated for $48 \mathrm{hrs}$ at $37^{\circ} \mathrm{C}$. Then, to provide a colony of bacteria, they were cultured for $48 \mathrm{hrs}$ on a solid medium of Brain Heart Infusion Agar-BHIA (Merck-Germany).

By using these colonies and with the help of physiologic serum, a suspension with a concentration of approximately 0.5 McFarland (1/5) was prepared. To provide a bacteria-containing agar medium, the BHIA medium was heated to $45-50{ }^{\circ} \mathrm{C}$ and then was poured into sterile disposable plates with a diameter of $10 \mathrm{~cm}$, so the thickness of agar reached $4 \mathrm{~mm}$. After the mixture was cooled, in each container using a sterile punch, five cavities with identical intervals and a diameter of four millimeters were formed. Then, the $0.5 \mathrm{McF}$ arland suspension was used to culture plates with a spread plate method. Into each cavity of a plate, the following materials were respectively put:

Pro Root MTA (Dentsply,Tulsa Dental,USA), Calcium Hydroxide (Kemdent-England), Zinc Oxide Eugenol (Kemdent-England), Metapex (Tejarat pars-Corea), and CEM-Cement (Tejarat pars-Iran).

ZOE, MTA, CH, and CEM-cement pastes were prepared based on their manufacturers' instructions, and the Metapex syringe was also available. The plates were incubated at $37{ }^{\circ} \mathrm{C}$ in the incubator. After 24,48 , and $72 \mathrm{hrs}$, a millimeter ruler with a precision of 0.5 millimeters which was independent of each observer in two locations perpendicular to each sample was used to measure the diameter of growth inhibition zones for each material in millimeters.

The results of each sample were entered into the statistical software of SPSS version 19 and analyzed by Kruskal-Wallis and Friedman tests. Level of significance was predetermined 0.05 as the basis for statistical judgments.

\section{Results}

The antibacterial activity of the tested materials on 5 types of bacteria at different times (the diameter of the growth inhibition zone was in millimeters). The highest mean diameter of growth inhibition zones was observed around $\mathrm{ZOE}$ and then $\mathrm{CH}$ and CEM-cement. According to the Kruskal-Wallis test, there was a significant difference among the tested groups $(P<0.041)$. All the root canal filling materials induced the formation of growth inhibition zones, except for MTA and Metapex.

The results of the Kruskal-Wallis test showed that on the antimicrobial activity for $24 \mathrm{hrs}$ of the five types of pastes against:

- P. aeruginosa, the $\mathrm{CH}$ was $20 \mathrm{~mm}$ and that of $\mathrm{ZOE}$ was $27 \mathrm{~mm}$, and the significant level was 0.039 and Chisquare was 10.102 .

$-E$. faecalis bacterium, the $\mathrm{CH}$ was $14 \mathrm{~mm}$ and that of ZOE was $19 \mathrm{~mm}$, and the significant level was calculated to be 0.018 and Chi-square was calculated to be 11.859 . 
-S. aureus bacterium, the ZOE was $35 \mathrm{~mm}$, and the significant level was calculated to be 0.008 and Chi-square was calculated to be 13.796 .

- B. subtilis bacterium, the $\mathrm{CH}$ was $17 \mathrm{~mm}$ and that of ZOE and CEM-cement were 25 and $14 \mathrm{~mm}$ respectively, and the significant level was calculated to be 0.027 and Chi-square was calculated to be 10.922 .

-C. albicans bacterium, the $\mathrm{CH}$ was $20 \mathrm{~mm}$ and that of ZOE and CEM-cement were 47 and $15 \mathrm{~mm}$ respectively, and the significant level was calculated to be 0.041 and Chi-square was calculated to be 90.941 .

The results of Friedman test on comparing the antimicrobial activity of the CEM-cement paste at different times, regardless of the type of bacterium, showed that the mean antimicrobial activity in $24,48,72 \mathrm{~h}$ were 1.93 , 1.93 , and 1.86 respectively, and the significance level was calculated to be 0.156 and Chi-square was calculated to be 3.714 (Figures 1 to 3 and Table 1).

\section{Discussion}

The key objective of pulp therapy is to remove microorganisms from root canals and prevent their subsequent infections; cleansing and shaping the canals and filling them completely result in the fulfillment of this goal. ${ }^{2}$ When the pulp is irreversibly affected or necrosed, a root canal treatment is carried out. However, the complex morphology of root canal in deciduous teeth makes mechanical cleansing and rinsing difficult. Consequently, to

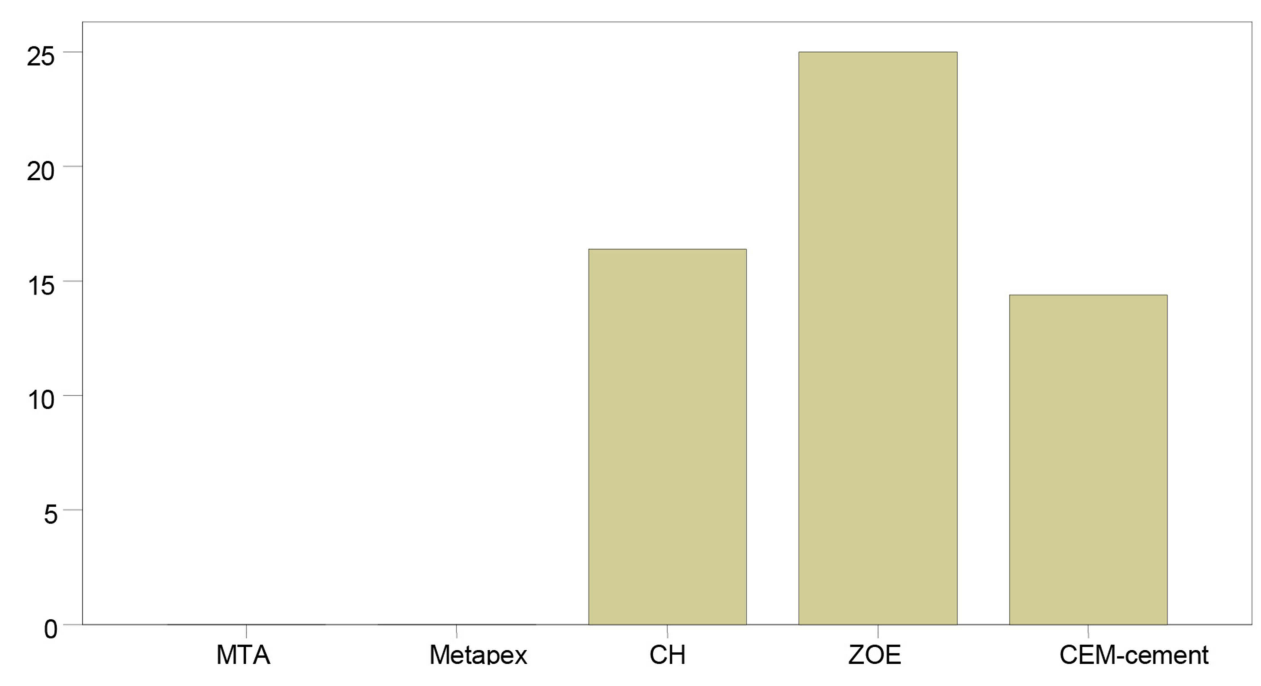

Figure I Mean antimicrobial activity of the materials in the first $24 \mathrm{hrs}$ against B. subtilis.Y axis is $\mathrm{mm}$.

Abbreviations: $B$. subtilis, Bacillus subtilis; MTA, mineral trioxide aggregate; CEM, CEM-cement; $\mathrm{CH}$, calcium hydroxide; ZOE, zinc oxide eugenol.

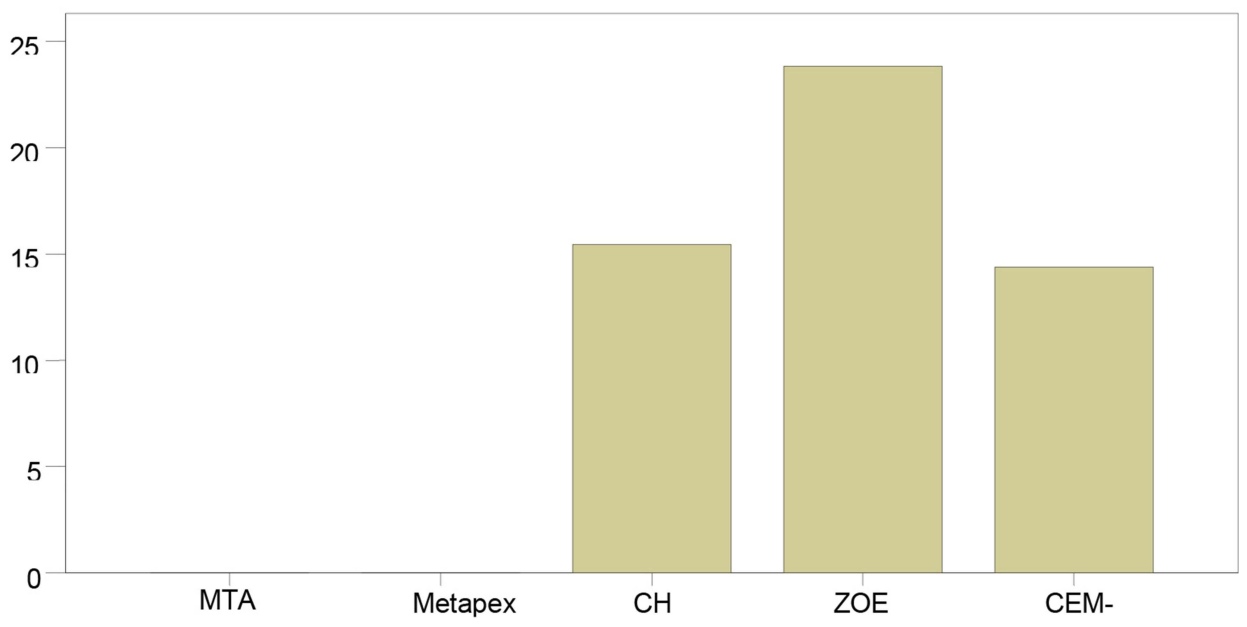

Figure 2 Mean antimicrobial activity of the materials in the first 72 hrs against $S$. aureus.

Abbreviations: S. aureus, Staphylococcus aureus; MTA, mineral trioxide aggregate; CEM, CEM-cement; CH, calcium hydroxide; ZOE, zinc oxide eugenol. 


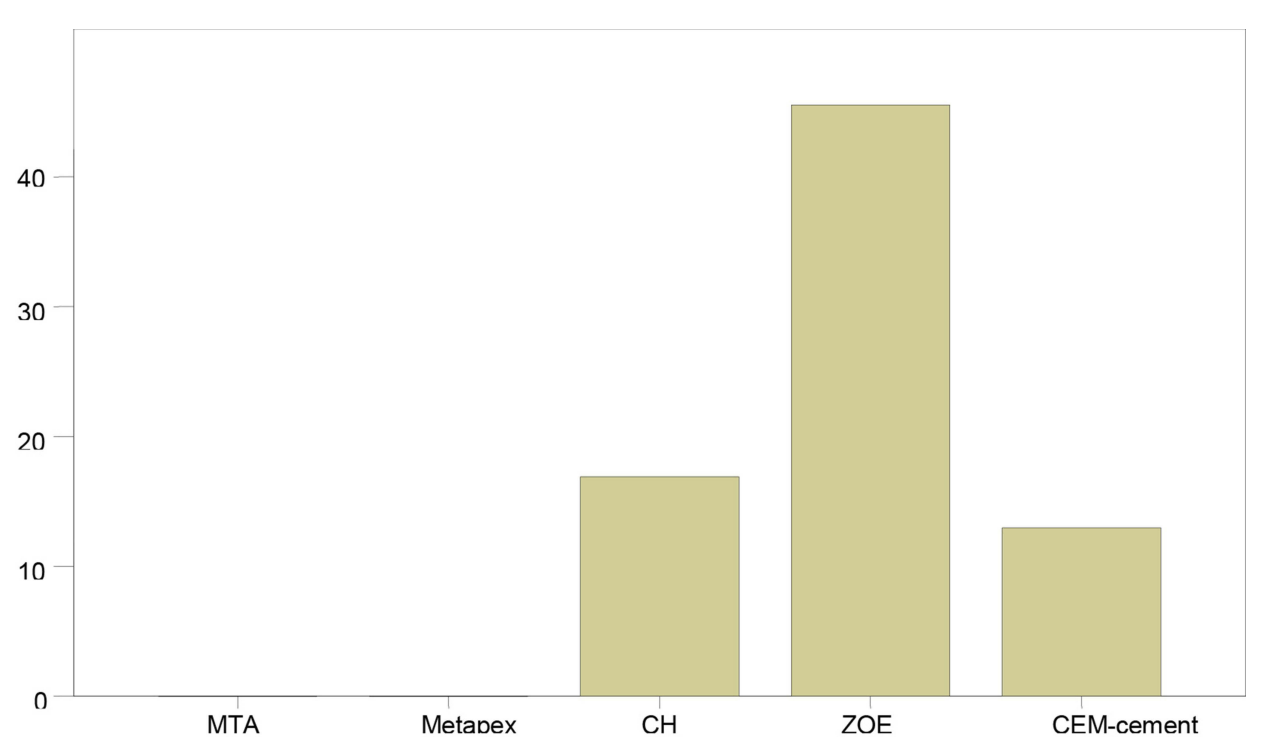

Figure 3 Mean antimicrobial activity of the materials in the first 72 hrs against $C$. albicans.

Abbreviations: C. albicans, Candida albicans; MTA, mineral trioxide aggregate; CEM, CEM-cement; $\mathrm{CH}$, calcium hydroxide; ZOE, zinc oxide eugenol.

Table I Antibacterial Activity Of The Tested Materials (millimeters) On 5 Types Of Bacteria At Different Times

\begin{tabular}{|c|c|c|c|c|c|c|}
\hline Microorganism & Time (hours) & MTA & Metapex & $\mathrm{CH}$ & CEM & ZOE \\
\hline \multirow[t]{3}{*}{ P. aeruginosa } & 24 & 0 & 0 & 20 & 0 & 27 \\
\hline & 48 & 0 & 0 & 19 & 0 & 27 \\
\hline & 72 & 0 & 0 & 17 & 0 & 27 \\
\hline \multirow[t]{3}{*}{ S. aureus } & 24 & 0 & 0 & 0 & 0 & 35 \\
\hline & 48 & 0 & 0 & 0 & 0 & 33 \\
\hline & 72 & 0 & 0 & 0 & 0 & 32 \\
\hline \multirow[t]{3}{*}{ E. faecalis } & 24 & 0 & 0 & 14 & 0 & 19 \\
\hline & 48 & 0 & 0 & 14 & 0 & 18 \\
\hline & 72 & 0 & 0 & 14 & 0 & 17 \\
\hline \multirow[t]{3}{*}{ B. subtilis } & 24 & 0 & 0 & 17 & 14 & 25 \\
\hline & 48 & 0 & 0 & 17 & 14 & 24 \\
\hline & 72 & 0 & 0 & 16 & 14 & 24 \\
\hline \multirow[t]{3}{*}{ C. albicans } & 24 & 0 & 0 & 20 & 15 & 47 \\
\hline & 48 & 0 & 0 & 17 & 15 & 46 \\
\hline & 72 & 0 & 0 & 17 & 14 & 45 \\
\hline
\end{tabular}

Abbreviations: P. aeruginosa, Speudamonas aeruginosa; S. aureus, Staphylococcus aureus; E. faecalis, Enterococcus faecalis; B. subtilis, Bacillus subtilis; C. albicans, Candida albicans; MTA, mineral trioxide aggregate; CEM, CEM-cement; $\mathrm{CH}$, calcium hydroxide; ZOE, zinc oxide eugenol.

increase the odds of success in root canal treatments, materials with high antimicrobial properties should be applied in filling root canals. ${ }^{3}$

In this in vitro study the antimicrobial activity of root canal filling pastes including MTA, ZOE, CEM-cement, Metapex, and Calcium-Hydroxide were evaluated in deciduous teeth. After analyzing the data, the results showed that the most antimicrobial activity was related to ZOE and after that, calcium hydroxide and CEM- cement had higher antimicrobial activity. The statistical difference between these materials was significant $(P$ $<0.039$ ). Metapex and MTA pastes did not show any antimicrobial activity at any time. The most resistant bacterium among these five microorganisms was $\mathrm{E}$ faecalis.

The results of Asgary et al's ${ }^{12}$ study were in line with those of the present one and they concluded that among calcium hydroxide, MTA, and Portland-cement, the highest antimicrobial activity after 24,48 , and $72 \mathrm{hrs}$ was observed in 
calcium hydroxide. Like our study, the most antimicrobial activity in all groups was found against Enterococcus faecalis. In a study by Lilian et $\mathrm{al}^{13}$, it was concluded that calcium hydroxide had antimicrobial activity against $S$. aureus, E. faecalis, $P$. aeruginosa, B. subtilis, and C. albicans and the rate of this activity was more than that of MTA. Vitapex had no antimicrobial activity. Estrela et $\mathrm{al}^{14}$ determined that calcium hydroxide had higher antimicrobial activity than MTA, Portland, Sealapex, and Dycal against $S$. aureus, E. faecalis, B. subtilis, and S. aureus.

In a study carried out by Tchaou et $\mathrm{al}^{15}$, like the present study, ZOE had a greater antibacterial effectiveness than calcium hydroxide and Vitapex. The bacterial, were collected from necrotic teeth of patients. For data analysis, non-parametric Friedman and Tukeys HSD tests were used.

Prathima et $\mathrm{al}^{16}$ showed in a study that ZOE had good zone of inhibition but when combined with Formocresol the zones of inhibition was increased indicating good antibacterial properties.

Holan and Fuks ${ }^{17}$ showed that the clinical efficacy of root filling with iodoform-containing paste (KRI) was superior to ZOE. ZOE irritated the periapical tissues around the root of teeth and underwent resorption later than the root tissue.

Mortazavi et $\mathrm{al}^{18}$ in their study concluded that the success rates of Vitapex and ZOE were 100\% and $78.5 \%$, respectively. Fisher's exact test was used to evaluate the data. Due to the more convenient application of Vitapex and its absorption in tissues around the root, this material can be a good alternative to ZOE, especially when there is a doubt on the patient's return for follow-up.

In a study by Khoramian et $\mathrm{al}^{19}$, they discovered that Diapaste, a calcium hydroxide root canal filling paste, had more antibacterial activity against $E$. faecalis than $\mathrm{ZOE}$ and Sealapex, a calcium hydroxide sealer. This study was performed in a laboratory and Kruskal-Wallis and MannWhitney tests were used to measure the antimicrobial properties of the materials only in the $48 \mathrm{hr}$ interval. According to the results of this study, calcium hydroxidebased root canal filling materials demonstrated their antimicrobial property by releasing the hydroxyl ion. Both Diapaste and Sealapex cement are calcium hydroxidebased sealers. In a systematic review by Barja-Fidalgo ${ }^{20}$ they concluded there seems to be no convincing evidence to support the superiority of any material over ZOE, and both ZOE and iodoform paste with calcium hydroxide appear to be suitable as root canal fillings for deciduous teeth. In the study by Queiroz et $\mathrm{al}^{21}$, the antimicrobial activity of ZOE was approved to be greater than that of Sealapex, a type of calcium hydroxide-based material.

Unlike our research, in a study carried out by Fabiane et $\mathrm{al}^{22}$, it was concluded that MTA had high levels of antimicrobial activity at different times, and no antibacterial activity was observed for $\mathrm{ZOE}$ and two calcium hydroxide-based products including Caien and L\&C direct exposure test was used. Ramar et $\mathrm{al}^{23}$ in a study depicted that Endofloss compared with Metapex and ZOE was a better material in the treatment of deciduous teeth. This study was conducted clinically. In the study by Subramaniam et $\mathrm{al}^{11}$, the highest clinical success rates were seen in Metapex (100\%). All three materials were in a statistically significant level and the study was carried out clinically.

Nadkarni et $\mathrm{al}^{24}$ in their study concluded that the use of calcium hydroxide in the treatment of deciduous teeth was more successful than the use of ZOE and calcium hydroxide could be used as an alternative to $\mathrm{ZOE}$. The study examined clinical and radiographic success rates. In a clinical study conducted by Barcelis et $\mathrm{al}^{25}$, it was concluded that the use of Vitapex and Sealapex in the treatment of deciduous teeth had a similar success rate. In the study by Asgari et $\mathrm{al}^{26}$, the antibacterial activity of calcium hydroxide and CEM-cement was similar and more than that of MTA.

Based on the results of this study, the following conclusions were obtained:

- The antibacterial effectiveness of ZOE was greater than that of other materials.

- The antibacterial strength of CEM-cement was higher than that of MTA.

- Metapex and MTA showed no antibacterial activity at any time interval.

- The most resistant bacterium among these five microorganisms was E. faecalis.

- As an alternative to ZOE, calcium hydroxide and then CEM-cement substitute can be considered.

However, more research is needed to compare the results of this study with those of previous studies and ponder more upon their contradictions.

\section{Ethical Clearance}

This article is based on a doctoral dissertation completed by Dr. Sahameh Ansarifar with Approved Code: u-92066 and taken from Ethics Committee of Ahvaz Jundishapur University of Medical Sciences. 


\section{Disclosure}

The authors report no conflicts of interest in this work.

\section{References}

1. Hibbard E, Ireland R. Morphology of root canal of the primary molar teeth. J Dent Child. 2007;24(4):250-257.

2. Estrela C, Bammann LL, Pimenta FC, Pecora JD. Control of microorganisms in vitro by calcium hydroxide pastes. Int Endod J. 2001;34 (5):341-345.

3. Bonow MLM, Guedes Pinto AC, Bammann LL. Antimicrobial activity of drugs used in pulp therapy of deciduous teeth. Braz Endod J. 1996;1(1):44-48.

4. Sweet CA. Procedure for treatment of exposed and pulpless deciduous teeth. J Am Dent Assoc. 1930;17(6):1150-1153. doi:10.14219/ jada.archive. 1930.0158

5. Barr ES, Flatiz CM, Hicks MJ. A retrospective radiographic evaluation of primary molar pulpectomies. Pediatr Dent. 1991;13(1):4-9.

6. Gould JM. Root canal therapy for infected primary molar teethpreliminary report. ASDC J Dent Child. 1972;39(4):269-273.

7. Pabla T, Gulati M, Mohan U. Evaluation of antimicrobial efficacy of various root canal filling materials for primary teeth. J Indian Soc Pedod Prev Dent. 1997;15(4):134-140.

8. Chawla HS, Setia S, Gupta N, Gauba K, Goyal A. Evaluation of a mixture of zinc oxide, calcium hydroxide, and sodium fluoride as a new root canal filling material for primary teeth. J Indian Soc Pedod Prev Dent. 2008;26(2):53-58.

9. Pitts DL, Jones JE, Oswald RJ. A histological comparison of calcium hydroxide plugs and dentin plugs used for the control of gutta-percha root canal filling material. J Endod. 1984;10(7):283-293. doi:10. 1016/S0099-2399(84)80180-6

10. Gupta S, Das G. Clinical and radiographic evaluation of zinc oxide eugenol and metapex in root canal treatment of primary teeth. J Indian Soc Pedod Prev Dent. 2011;29(3):222-228. doi:10.4103/0970-4388. 85829

11. Subramaniam P, Gilhotra K. Endoflas, zinc oxide eugenol and metapex as root canal filling materials in primary molars-a comparative clinical study. J Clin Pediatr Dent. 2011;35(4):365-369.

12. Asgary S, Kamrani FA. Antibacterial effects of five different root canal sealing materials. J Oral Sci. 2008;50(4):469-474.

13. Lilian G, Orlando A. Antimicrobial analysis of different root canal filling pastes used in pediatric dentistry by two experimental methods. Braz Dent J. 2006;17(4):317-322.
14. Estrela C, Bammann LL, Estrela CR, Silva RS, Pecora JD. Antimicrobial and chemical study of MTA, Portland cement, calcium hydroxide paste, sealapex and dycal. Braz Dent J. 2000;11(1):3-9.

15. Tchaou WS, Turng BF, Minah GE, Coll JA. In vitro inhibition of bacteria from root canals of primary teeth by various dental materials. Pediatr Dent. 1995;17(5):351-355.

16. Prathima GS, Sudha P. An in vitro inhibition of bacteria from mixed culture by five root canal materials. Int J Contemp Dent. 2011;2 (6):54-60.

17. Holan G, Fuks AB. A comparison of pulpectomies using ZOE and KRI paste in primary molars: a retrospective study. Pediatr Dent. 1993;15(6):403-407.

18. Mortazavi M, Mesbahi M. Comparison of zinc oxide and eugenol, and vitapex for root canal treatment of necrotic primary teeth. Int $J$ Paediatr Dent. 2004;14(6):417-424. doi:10.1111/j.1365-263X.2004. 00544.x

19. Khoramian Tusi S, Bagherian A, Bahram Abadi R, Zeynali B. Comparison of antibacterial effect between diapaste with sealapex and ZOE against enterococcus faecalis: a laboratory study. $J$ Mashhad Dent Sch. 2013;37(2):119-126.

20. Barja-Fidalgo F, Moutinho-Ribeiro M, Oliveira MA, de Oliveira BH. A systematic review of root canal filling materials for deciduous teeth: is there an alternative for zinc oxide-eugenol? ISRN Dent. 2011;2011:367318.

21. Queiroz AM, Nelson-Filho P, Silva LA, Assed S, Silva RA, Ito IY. Antibacterial activity of root canal filling materials for primary teeth: zinc oxide and eugenol cement, calen paste thickened with zinc oxide, sealapex and EndoREZ. Braz Dent J. 2009;20(4):290-296.

22. Fabiane P, Faraco Junior IM, Estrela C. Antimicrobial activity of different root canal filling pastes used in deciduous teeth. Mat Res. 2008;11(2):171-173. doi:10.1590/S1516-14392008000200010

23. Ramar K, Mungara J. Clinical and radiographic evaluation of pulpectomies using three root canal filling materials: an in-vivo study. $J$ Indian Soc Pedod Prev Dent. 2010;28(1):25-29. doi:10.4103/09704388.60481

24. Nadkarni U, Damle SG. Comparative evaluation of calcium hydroxide and zinc oxide eugenol as root canal filling materials for primary molars: a clinical and radiographic study. J Indian Soc Pedod Prev Dent. 2000;18(1):1-10.

25. Barcelos R, Santos MP, Primo LG, Luiz RR, Maia LC. ZOE paste pulpectomies outcome in primary teeth: a systematic review. $J$ Clin Pediatr Dent. 2011;35(3):241-248.

26. Asgary S, Akbari Kamrani F, Taheri S. Evaluation of antimicrobial effect of MTA, calcium hydroxide, and CEM cement. Iran Endod J. 2007;2(3):105-109.
Clinical, Cosmetic and Investigational Dentistry

\section{Publish your work in this journal}

Clinical, Cosmetic and Investigational Dentistry is an international, peer-reviewed, open access, online journal focusing on the latest clinical and experimental research in dentistry with specific emphasis on cosmetic interventions. Innovative developments in dental materials, techniques and devices that improve outcomes and patient satisfaction and preference will be highlighted. The manuscript management system is completely online and includes a very quick and fair peer-review system, which is all easy to use. Visit http://www.dovepress.com/testimonials.php to read real quotes from published authors.

Submit your manuscript here: https://www.dovepress.com/clinical-cosmetic-and-investigational-dentistry-journal 